References

1. Arnett F. C., Edworthy S. M., Bloch D. A., McShane D. J., Fries J. F. et al. The American Rheumatism Association 1987 revised criteria for the classification of rheumatoid arthritis. Arthritis Rheum. 1988;31:315324. doi: 10.1002/art.1780310302

2. Aletaha D., Neogi T., Silman A. J., Funovits J., Felson D. T. et al. 2010 Rheumatoid arthritis classification criteria: an American College of Rheumatology/ European League Against Rheumatism collaborative initiative. Arthritis Rheum. 2010;62:2569-2581. doi:10.1002/art.27584

3. Balabanova R. M., Erdes S. F. Rasprostranennost' revmaticheskih zabolevanij v Rossii v 2013-2014 gg. Nauchnoprakticheskaja revmatologija. 2014;53(2):120-124.

4. Ehling A., Schäffler A., Herfarth H., Tarner I. H., Anders S. et al. The potential of adiponectin in driving arthritis. J. Immunol. 2006; 176(7):4468-4478.

5. Gómez-Vaquero C., Nolla J. M., Fiter J., Ramon J. M., Concustell R. et al. Nutritional status in patients with rheumatoid arthritis. Joint Bone Spine. 2001:68(5):403-409.

6. Gremese E., Carletto A., Padovan M., Atzeni F., Raffeiner B. et al. Gruppo Italiano di Studio sulle Early Arthritis (GISEA). Obesity and reduction of the response rate to anti-tumor necrosis factor $\alpha$ in rheumatoid arthritis: an approach to a personalized medicine. Arthritis Care Res (Hoboken). 2013;65(1):94-100. doi: 10.1002/acr.21768

7. Hodkinson B., Tikly M., Adebajo A. Rheumatoid arthritis in the developing world: stepping up to the challenge. Clin Rheumatol. 2014;33(9):1195-1196. doi: 10.1007/s10067-014-2690-3

8. Imrich R., Vlcek M., Aldag J. C., Kerlik J., Radikova $Z$. et al. An endocrinologist's view on relative adrenocortical insufficiency in rheumatoid arthritis. Ann N Y Acad Sci. 2010;1193:134-138. doi: 10.1111/j.17496632.2009.05362.x
9. Laurberg T. B., Frystyk J., Ellingsen T., Hansen I. T., Jørgensen A. et al. Plasma adiponectin in patients with active, early, and chronic rheumatoid arthritis who are steroid- and disease-modifying antirheumatic drugnaïve compared with patients with osteoarthritis and controls. J. Rheumatol. 2009;36(9):1885-1891. doi: 10.3899/jrheum.080907

10. Lee Y. A., Ji H. I., Lee S. H., Hong S. J., Yang H. I. et al. The role of adiponectin in the production of IL-6, IL-8, VEGF and MMPs in human endothelial cells and osteoblasts: implications for arthritic joints. Exp. Mol. Med. 2014;46:e72. doi: 10.1038/emm.2013.141

11. Otero M., Lago R., Gomez R., Lago F., Dieguez C. et al. Changes in plasma levels of fat-derived hormones adiponectin, leptin, resistin and visfatin in patients with rheumatoid arthritis. Ann. Rheum. Dis. 2006;65(9):1198-1201

12. Szekanecz Z, Kerekes G., Dér H. Sándor Z Szabó Z. et al. Accelerated atherosclerosis in rheumatoid arthritis. Ann N Y Acad Sci. 2007;1108:349-358.

13. Wang Y., Wang X., Lau W. B., Yuan Y., Booth D. et al. Adiponectin inhibits tumor necrosis factor- $\alpha$-induced vascular inflammatory response via caveolin-mediated ceramidase recruitment and activation. Circ Res. 2014;114(5):792-805. doi: 10.1161/CIRCRESAHA. 114.302439

14. Weyer C., Funahashi T., Tanaka S., Hotta K., Matsuzawa Y. et al. Hypoadiponectinemia in obesity and type 2 diabetes: close association with insulin resistance and hyperinsulinemia. J. Clin. Endocrinol. Metab. 2001:86(5):1930-1935.

15. World Health Organization Report. Obesity: preventing and managing the global epidemic. WHO Obesity Technical Report Series 894. - World Health Organization: Geneva (Switzerland). 2004. http:// www.who.int/nutrition/publications/obesity/WHO_ TRS_894/en/.

About authors:

Oranskiy Sergey, MD; Associate Professor, Department of Faculty Therapy; tel.: +79183671067; e-mail: s_oransky@inbox.ru

Yeliseyeva Lyudmila, MD, PhD; Head of Faculty Therapy Division; e-mail: yeliseyeva@mail.ru

(C) Group of authors, 2016

UDC 616.379-008:616-056.52:612.017.12

DOI - http://dx.doi.org/10.14300/mnnc.2016.11020

ISSN $-2073-8137$

\title{
ASSOCIATION OF INSULIN RESISTANCE AND OBESITY WITH IMPAIRED IMMUNE RESPONSE TO HEPATITIS B VACCINATION IN HEALTH CARE WORKERS
}

\author{
Tkachenko L. I. ${ }^{1}$, Maleyev V. V. ${ }^{2}$, Rtishcheva L. V. ${ }^{1}$ \\ 1 Stavropol State Medical University, Russian Federation \\ 2 Central Research Institute of Epidemiology, Moscow, Russian Federation

\section{АССОЦИАЦИЯ ИНСУАИНОРЕЗИСТЕНТНОСТИ И ОЖИРЕНИЯ С НЕЭФФЕКТИВНОСТЬЮ ВАКЦИНАЦИИ ОТ ВИРУСНОГО ГЕПАТИТА В У МЕАИЦИНСКИХ РАБОТНИКОВ}

\author{
А. И. Ткаченко', В. В. Малеев ${ }^{2}$, Ртищева А. В. ${ }^{1}$ \\ 1 Ставропольский госуАарственный меАицинский университет, Российская ФеАерация \\ 2 Центральный научно-исслеАоватеАьский институт эпиАемиологии, \\ Москва, Российская ФеАерация
}

At the study was to evaluate immune response to HBV vaccine in Health care workers (HCWs) and detect risk factors of non-responsible persons. Descriptive retrospective analyses of antibodies' titer dynamics in 98 HBV vaccinated HCWs conducted from 1998 to 2011 years annually were evaluated by measuring serum HBsAb levels, by ob- 
jective state and on the main laboratory results taken in medical documents. After vaccination negative response $($ aHBs $<10 \mathrm{mlU} / \mathrm{ml}$ ) was in $20.4 \%$, poor immune response $($ aHBs $>10 \mathrm{mlU} / \mathrm{ml}<100 \mathrm{mlU} / \mathrm{ml})-$ in $34.7 \%$ and high immune response (aHBs>100 mlU/ml) - in $44.9 \%$ HCWs. Obesity, insulin resistance, age over 40 years, male gender and low level of $25(\mathrm{OH})$ D were associated with negative response to vaccination. In titer aHBs $<100 \mathrm{mIU} / \mathrm{ml}$, patients became seronegative in three years after vaccination. In high immune response, patients stay seropositive during 10 years. The introduction of a booster dose of the vaccine and activating cellular immunity, can improve the immunogenicity of the vaccine. Thus obesity insulin resistance, inadequate supply of $25(\mathrm{OH}) \mathrm{D}$, age over 40 years and male gender were associated with non response to vaccination. It's necessary to follow-up of the primary immune response in HCWs in order to specify the additional doses of the vaccine in seronegative patients.

Key words: vaccination, immune response, hepatitis $B$, insulin resistance, obesity, health care workers

В работе проводится анализ формирования иммунного ответа у медицинских работников, вакцинированных от вирусного гепатита В, а также выявлялись факторы риска по отсутствию сероконверсии после вакцинации. Среди 98 медицинских работников был проведен ретроспективный анализ динамики титра антител к HBsAg (aHBs) после вакцинации в 1998-2011 гг. с оценкой данных объективного статуса и основных лабораторных показателей. Из числа вакцинированных отсутствие ответа (aHBs $<10 \mathrm{mlU} / \mathrm{ml}$ ) наблюдалось у $20,4 \%$, слабый ответ (aHBs $>10 \mathrm{mlU} / \mathrm{ml}<100 \mathrm{mlU} / \mathrm{ml}$ ) - у 34,7 \% и полный ответ (aHBs $>100 \mathrm{mlU} / \mathrm{ml}$ ) - y 44,9 \% сотрудников. Ожирение, инсулинорезистентность, возраст старше 40 лет, а также неадекватная обеспеченность 25(OH)D и мужской пол были сопряжены с неэффективностью вакцинации. При титре aHBs $<100 \mathrm{mlU} / \mathrm{ml}$ пациенты становились серонегативными в течение трех лет после иммунизации. Введение бустерной дозы вакцины позволяло повысить иммуногенность вакцины. Таким образом, с отсутствием формирования сероконверсии были сопряжены ожирение, инсулинорезистентность, возраст старше 40 лет и мужской пол. Необходимо мониторировать первичный иммунный ответ с целью своевременного введения бустерной дозы вакцины.

Ключевые слова: вакцинация, иммунный ответ, вирусный гепатит В, инсулинорезистентность, ожирение, работники здравоохранения

nfection with hepatitis B virus (HBV) and its consequences, including chronic liver disease, cirrhosis and hepatocellular carcinoma is a significant public health problem. According to WHO data, there are about 240 million patients with chronic hepatitis B. Each year, nearly 4 million cases of acute hepatitis $B$ with clinical manifestations are recorded and about 7 million persons become chronically infected. The number of deaths due to acute hepatitis $B$ and outcomes of chronic infection is estimated as $\mathbf{7 8 0}$ thousand per year [19]. The high mortality rates of HBVinfection put it to the 9th place among the leading causes of death in the world. Persons infected with hepatitis $B$ virus are at risk for hepatocellular carcinoma (HCC) 25 times higher than uninfected ones, and $50-55 \%$ of HCC cases are connected with HBV-infection [11].

In unvaccinated individuals the risk of HBV infection after a single exposure to blood or body fluids ranges from 6 to $30 \%$. In view of repeated contact with the source of infection, health care workers are at risk of contamination with hepatitis $B$ virus [10].

Through the implementation of the WHO Public Immunization Program since 1991, the incidence of acute hepatitis B decreased significantly in all countries. Since 1997, the Center for Disease Control (CDC) in the United States recommended vaccination against HBV of all health care workers [8].

Conducting of mass immunization against hepatitis $B$ in the Russian Federation has allowed to reduce the incidence of acute hepatitis B 5 times: from 8.6 in 2005 to 1.71 per 100 thousand population in 2011 , and to achieve the lowest level of disease by 2013: 1.3 per 100 thousand population for all years of observation

Despite the recommendations of the $\mathrm{WHO}$, and high risk of contamination after exposure, vaccination commitment among various medical communities remains low [3]. Coverage of vaccination against hepatitis $B$ of the medical staff, whose work is associated with a high risk of exposure to occupational HBV, is more than
$93 \%$ in the whole of the Russian Federation; however, at some medical organizations of individual subjects of the Russian Federation the coverage is insufficient - from $31 \%$ to $74 \%$ [7].

The level of antibodies to HBsAg (aHBs) in a titer greater than $10 \mathrm{mlU} / \mathrm{ml}$ is considered protective $[3,4]$. Vaccine-induced immunity to HBV vaccine is formed within 6-8 weeks after the immunization.

Factors associated with low immune response include older age, smoking, obesity, gender and genetic features $[5,18]$. The role of insulin resistance and serum level of $25(\mathrm{OH}) \mathrm{D}$ in the immune response, in practice, has not been studied. Previous studies of the immune response to HBV vaccination of health care workers showed that seroconversion does not develop in 12-21\% [12, 14, 15, 16$]$.

The aim of study was to analyze the immune response development, the intensity and persistence of immunity in health care workers, to identify possible reasons for the absence of seroconversion to the vaccination against viral hepatitis $\mathrm{B}$ depending on the body mass index, insulin resistance and level of 25(OH)D.

Material and Methods. A retrospective analysis of immunization in 98 health care workers was conducted at Regional clinical diagnostic center, Stavropol, Russia. The aHBs titer was determined before vaccination and every year after vaccination. Follow-up period was 13 years (1998-2011).

The medical staff were vaccinated in the deltoid region three times (scheme 0-1-6 months) with a recombinant vaccine (Engerix $B$, Glaxo Smith Kline Biological). Adult dose is $20 \mu \mathrm{g} / \mathrm{ml}$ of virus B surface antigen. Patients with chronic hepatitis B or previously vaccinated against this infection, were excluded. The post-vaccination immunity stress was determined by a quantitative method. The level of aHBs more than 10 $\mathrm{mIU} / \mathrm{ml}$ is considered an indicator of a positive response to vaccination, lower than $10 \mathrm{mIU} / \mathrm{ml}$ indicated the absence of a response.

The results of studies of post-vaccination aHBs were evaluated on key criteria of immunological effectiveness: the seroconversion rate and quantitative level of specific 
antibodies. Response to vaccination was estimated according to gender differences, the patient's age, body mass index, carbohydrate and fat metabolism.

Body mass index (BMI) was calculated by Ketle method $\left(\mathrm{kg} / \mathrm{m}^{2}\right)$, followed by distribution in groups according to the WHO's criteria of obesity (1997). Presence of insulin resistance was estimated according to the criteria of the European Group for the Study of IR - EGIR, 2002 with calculation of the HOMA index (Homeostasis Model of Assessment - Insulin Resistance (HOMA-IR)) [(fasting blood glucose $(\mathrm{mmol} / \mathrm{l}) \times$ fasting insulin $\mathrm{mkU} / \mathrm{L}) / 22,5]$. Presence of IR was confirmed at HOMA-IR index equal to or more than 2.77 .

The real level of seroprotection (LSP) was calculated using the formula proposed by J. Poorolajal (2009) [17]:

$$
\mathbf{L S P}=[\mathbf{P P}+(\mathbf{P N P} \times \mathbf{P A I R})] \times \mathbf{1 0 0} .
$$

LSP is the sum of the proportion of protected (PP) and the product of the proportion of non-protected subjects (PNP) and the proportion of non-protected with anamnestic immune response (PAIR).

Laboratory studies included investigation levels of aHBs, HBsAg, aHBc (Abbot Ax SYM Abbot Laboratories and ELISA DiaSorin). Biochemical parameters: serum bilirubin, serum activity of ALT, AST, GGT, alkaline phosphatase, blood glucose were measured with the analyzer KoneLab30, lipid profile parameters - with the unit OLYMPUS AU400, blood insulin with the analyzer UniCeIDxl 800 . The concentration of $25(\mathrm{OH})$ $\mathrm{D}$ in the blood was determined from April to October with the unit Cobas-e 411. The best considered and adequate serum $25(\mathrm{OH}) \mathrm{D} \geq 30 \mathrm{ng} / \mathrm{ml}$. Under the deficiency of $25(\mathrm{OH}) \mathrm{D}$, most authors determined serum levels $<9 \mathrm{ng} / \mathrm{ml}$, range between 10 and $30 \mathrm{ng} / \mathrm{ml}$ - failure, and the term an inadequate supply apply at the level of $25(\mathrm{OH}) \mathrm{D}<30 \mathrm{ng} / \mathrm{ml}$.

Statistical analyses were performed using SPSS version 17.0 for Windows (SPSS Inc., USA). The data of variables are presented as medians and interquartile span (Me [q1-q3]). Comparisons between groups were made using Student's t-test and ANOVA for normally distributed variables, while the Mann-Whitney $U$ test and KruskallWallis variance analysis were used for parametric variables with non-normal distributions. To assess the significance of differences in quality indicators we used contingency tables with calculation of indicators Chi-square test, the relative risk (RR) and their corresponding $95 \%$ confidence intervals $(95 \% \mathrm{Cl})$. Confidence interval and $p$-value for the difference between the shares were received on the basis of the criterion $z$ calculation. A $p$-value of less than 0.05 was considered statistically significant.

Results and Discussion. In the study were enrolled 98 health care workers, women made up a slight majority of $60.2 \%(59 / 98)$. The age at vaccination was 33.7 (25 to 47.8 ) years. Depending on the age the patients were randomized into 4 groups: younger than $25-22.4 \%$ (22/98), 25-34 years old $-28.6 \%$ (28/98), 35-49 years old $-40.8 \%(40 / 98)$, over 50 years old $-8.2 \%(8 / 98)$. Eight people $(8.1 \%)$ were positive for aHBc with negative results of aHBs, HBsAg and HBV DNA. Most of the medical staff, $53.1 \%(52 / 98)$, were vaccinated in 1998, the rest from 2003 to 2007. In a year after vaccination 78 persons (79.6\%) were seropositive for aHBs; 34 persons $(34.7 \%)$ have antibody titer within $\geq 10 \mathrm{mlU} / \mathrm{ml}<100 \mathrm{mlU} / \mathrm{ml}$, and $44-\geq 100(44,9 \%) \mathrm{mlU} / \mathrm{ml}$.

No significant differences in the immunological response to the vaccine, based on gender signs, were obtained $(z=1.92 ; p=0.38)$. The median age of the patients who did not respond to immunization was 46.0 (39-49) years, of the patients who had a positive response to vaccination, $-32.0(21.0-42.5) p=0.025$ With increasing age the percentage of response to vaccination decreased significantly $(p<0.001)$ (Table 1$)$.
Table 1

The Answer to the vaccination in the dependence on Gender, Age, BMI, HOMA and 25(OH)D

\begin{tabular}{|c|c|c|c|c|c|}
\hline $\begin{array}{c}\text { Characte- } \\
\text { ristics }\end{array}$ & \begin{tabular}{|c|} 
Normal \\
respond- \\
ers \\
$\mathrm{N}=78$ \\
\end{tabular} & $\begin{array}{c}\text { Nonre- } \\
\text { spond- } \\
\text { ers } \\
\mathrm{N}=20 \\
\end{array}$ & $x^{2}$ & $\begin{array}{c}p \text {-Val- } \\
\text { ue }\end{array}$ & $\begin{array}{c}\text { R R } \\
(95 \% \mathrm{CI})\end{array}$ \\
\hline \multicolumn{6}{|c|}{ Gender n(\%) } \\
\hline $\begin{array}{l}\text { Female } \\
\mathrm{N}=59 \\
\text { Male } \mathrm{N}=39\end{array}$ & $\begin{array}{c}49 \\
(83.1 \%) \\
29 \\
(74.4 \%)\end{array}$ & $\begin{array}{c}10 \\
(16.9 \%) \\
10 \\
(25.6 \%)\end{array}$ & 1.9 & 0.169 & $\begin{array}{c}1.5 \\
(0.9-2.6)\end{array}$ \\
\hline \multicolumn{6}{|c|}{ Age group $\mathrm{n}(\%)$} \\
\hline $\begin{array}{l}<25 \text { years } \\
N=22 \\
25-34 \text { years } \\
N=28 \\
35-49 \text { years } \\
N=40 \\
\geq 50 \text { years } \\
N=8\end{array}$ & $\begin{array}{c}22 \\
(100 \%) \\
25 \\
(89.3 \%) \\
24 \\
(60 \%) \\
3 \\
(37.5 \%)\end{array}$ & \begin{tabular}{|c|}
0 \\
3 \\
$(10.7 \%)$ \\
16 \\
$(40 \%)$ \\
5 \\
$(62.5 \%)$ \\
\end{tabular} & $\begin{array}{l}9.6 \\
20.6 \\
8.8\end{array}$ & $\begin{array}{l}0.002 \\
<0.001 \\
0.003\end{array}$ & $\begin{array}{c}3.6 \\
(1.9-6.7) \\
1.6 \\
(1.2-2.1)\end{array}$ \\
\hline \multicolumn{6}{|c|}{ BMI kg/m² n(\%) } \\
\hline $\begin{array}{l}<25(n=48) \\
25-29.9 \\
(n=32) \\
\geq 30(n=18) \\
<25 v s>30\end{array}$ & $\begin{array}{c}46(95.8 \%) \\
22 \\
(68.8 \%) \\
10(55.6 \%)\end{array}$ & $\begin{array}{c}2(4.2 \%) \\
10 \\
(31.2 \%) \\
8(44.4 \%)\end{array}$ & $\begin{array}{c}23.3 \\
\\
3.1 \\
43.9\end{array}$ & $\begin{array}{c}<0.001 \\
0.08 \\
<0.001\end{array}$ & $\begin{array}{c}7.8 \\
(2.8-21.4) \\
1.4(1.0-2.0) \\
11.1(4.1-29.7)\end{array}$ \\
\hline \multicolumn{6}{|c|}{ HOMA-IR(Glucose x Insulin)/22.5 n(\%) } \\
\hline $\begin{array}{l}\leq 2(n=56) \\
>2 \leq 3 \\
(n=24) \\
>3(n=18) \\
\leq 2 \text { vs>3 }\end{array}$ & $\begin{array}{c}52 \\
(92.8 \%) \\
18 \\
(75.0 \%) \\
8 \\
(44.4 \%)\end{array}$ & $\begin{array}{c}4 \\
(7.2 \%) \\
6 \\
(25.0 \%) \\
10 \\
(55.6 \%)\end{array}$ & $\begin{array}{l}10.8 \\
18.6 \\
55.6\end{array}$ & $\begin{array}{l}0.001 \\
<0.001 \\
<0.001\end{array}$ & $\begin{array}{l}3.6(1.6-7.9) \\
2.2(1.5-3.3) \\
7.9(3.8-16.6)\end{array}$ \\
\hline \multicolumn{6}{|c|}{$25(\mathrm{OH}) \mathrm{D} \mathrm{n}(\%)$} \\
\hline $\begin{array}{l}\geq 30(n=68) \\
\leq 30(n=30)\end{array}$ & $\begin{array}{c}64 \\
(94.1 \%) \\
14 \% \\
(46.7 \%)\end{array}$ & $\begin{array}{c}4 \\
(5.9 \%) \\
16 \\
(53.3 \%)\end{array}$ & 50.9 & $<0.001$ & $\begin{array}{c}8.8 \\
(3.9-19.6)\end{array}$ \\
\hline
\end{tabular}

The Chi-square test was used to calculate the $P$ value.

When analyzing the response to vaccination according to HOMA-IR by the criterion z, significant differences are obtained in the groups of patients with HOMA-IR $<2$ and $>3(p<0.001)$, the relative risk of a lack of seroconversion increased to 7.9 (95\% Cl 3.8-16.6). According to the criterion $\chi^{2}$ deteriorating response to vaccination was associated with an increase of HOMA-IR for each position more than 2.

At BMl of less than $25.0 \mathrm{~kg} / \mathrm{m}^{2}$, only 2 patients did not respond to the vaccine. In overweight $(\mathrm{BMl} \geq 25$ to $<30$ $\left.\mathrm{kg} / \mathrm{m}^{2}\right)$ and obesity $\left(\mathrm{BMl} \geq 30 \mathrm{~kg} / \mathrm{m}^{2}\right)$ the response to vaccination decreased significantly (both by the criterion $z$, and by $\chi^{2}$ ), the difference in response to immunization in patients with obesity and overweight is not obtained. The relative risk of non-responding to the vaccine also increased accordingly with age and BMI. In the overweight patients $\left(\mathrm{BMl} \geq 25<30 \mathrm{~kg} / \mathrm{m}^{2}\right)$, the relative risk of lack of seroconversion compared with patients having normal weight $\left(\mathrm{BMl}<25 \mathrm{~kg} / \mathrm{m}^{2}\right)$ was $7.8(95 \% \mathrm{Cl} 2,84-21,4)$, and in patients with obesity $\left(\mathrm{BMl} \geq 30 \mathrm{~kg} / \mathrm{m}^{2}\right)$ it was $11.1(95 \%$ Cl 4.1-29.7)

An inadequate supply of $25(\mathrm{OH}) \mathrm{D}$ was connect with negative response to vaccination. The relative risk of non-responding to the vaccine also increased accordingly with low level of $25(\mathrm{OH}) \mathrm{D}$, and it was 8.8 (95\% Cl 3.9-19.6).

The employees, seronegative after vaccination, had significantly higher rates of insulin, HOMA-IR, BMI, 
cholesterol, triglycerides, LDL, C-reactive protein and low level of 25(OH)D (Table 2). Thus, the patients who have not responded to vaccination had abdominal obesity and insulin resistance.

Comparison of probable factors responsible for non-response to vaccination in participants

\begin{tabular}{|c|c|c|c|}
\hline $\begin{array}{l}\text { Character- } \\
\text { istics } \\
\text { Median } \\
\text { (q1-q3) }\end{array}$ & $\begin{array}{c}\text { Normal } \\
\text { responders } \\
(n=78)\end{array}$ & $\begin{array}{c}\text { Non- } \\
\text { responders } \\
(n=20)\end{array}$ & P-Value \\
\hline BMI kg/m² & $\begin{array}{c}24.3 \\
(21.9-27.9)\end{array}$ & $\begin{array}{c}30.1 \\
(27.0-35.0)\end{array}$ & $<0.001$ \\
\hline $\begin{array}{l}\text { Waist } \\
(\mathrm{cm})\end{array}$ & $\begin{array}{c}78.2 \\
(67.1-84.6) \\
\end{array}$ & $\begin{array}{c}102.2 \\
(96.5-112.8) \\
\end{array}$ & $<0.001$ \\
\hline $\begin{array}{l}\text { Waist-Hip } \\
\text { Ratio }\end{array}$ & $0.8 \pm 0.1$ & $0.99 \pm 0.12$ & $<0.001$ \\
\hline $\begin{array}{l}\text { Fasting } \\
\text { plasma } \\
\text { glucose } \\
(\mathrm{mmol} / \mathrm{l})\end{array}$ & $\begin{array}{c}5.2 \\
(4.1-5.5)\end{array}$ & $\begin{array}{c}5.5 \\
(4.6-7.0)\end{array}$ & 0.51 \\
\hline $\begin{array}{l}\text { Insulin } \\
\ldots \mu \mathrm{U} / \mathrm{ml}\end{array}$ & $\begin{array}{c}8.0 \\
(7-10.7) \\
\end{array}$ & $\begin{array}{c}12.2 \\
(10.0-14.0)\end{array}$ & $<0.001$ \\
\hline $\begin{array}{l}\text { HOMA } \\
\text {-score }\end{array}$ & $\begin{array}{c}1.9 \\
(1.5-2.4) \\
\end{array}$ & $\begin{array}{c}3.1 \\
(2.3-3.6) \\
\end{array}$ & 0.001 \\
\hline $\begin{array}{l}\text { Total Cho- } \\
\text { lesterol } \\
\mathrm{mmol} / \mathrm{l}\end{array}$ & $\begin{array}{c}4.9 \\
(3.8-5.5)\end{array}$ & $\begin{array}{c}5.7 \\
(5.1-7.0)\end{array}$ & $<0.001$ \\
\hline $\begin{array}{l}\text { Triglycerides } \\
\mathrm{mmol} / \mathrm{l}\end{array}$ & $\begin{array}{c}1.2 \\
(0.6-1.2) \\
\end{array}$ & $\begin{array}{c}1.4 \\
(0.8-2.1) \\
\end{array}$ & $<0.001$ \\
\hline $\begin{array}{l}\mathrm{HDL} \\
\mathrm{mmol} / \mathrm{I}\end{array}$ & $\begin{array}{c}1.4 \\
(1.1-1.5) \\
\end{array}$ & $\begin{array}{c}1.2 \\
(1.0-1.5) \\
\end{array}$ & 0.873 \\
\hline $\begin{array}{l}\mathrm{LDL} \\
\mathrm{mmol} / \mathrm{I}\end{array}$ & $\begin{array}{c}2.9 \\
(1.9-3.3) \\
\end{array}$ & $\begin{array}{c}3.4 \\
(2.6-3.9) \\
\end{array}$ & 0.001 \\
\hline $\begin{array}{l}25(\mathrm{OH}) \mathrm{D} \\
\mathrm{ng} / \mathrm{ml}\end{array}$ & $\begin{array}{c}41.0 \\
(32.0-54.0) \\
\end{array}$ & $\begin{array}{c}17.0 \\
(10.0-22.0) \\
\end{array}$ & 0.001 \\
\hline CRP mg/l & $\begin{array}{c}1.5 \\
(0.4-2.0)\end{array}$ & $\begin{array}{c}5.0 \\
(3.2-7.9)\end{array}$ & 0.001 \\
\hline
\end{tabular}

BMI - Body Mass Index (kg/m2); HOMA - homeostasis model assessment;

the Mann - Whitney test was used to calculate the $P$ value.

When analyzing aHBs titer after vaccination in patients younger and older than 40 years, with a gradation of aHBs level $<100 \mathrm{mlU} / \mathrm{ml}$ and $\geq 100 \mathrm{mlU} / \mathrm{ml}$ we revealed significant conjugation of a weak immune response in individuals older than 40 years, $p<0,001$. Weak immune response was also associated with male $\operatorname{sex}(p=0.016)$ (Table 3).

The contingency table between the two levels of immune response and demographic data

\begin{tabular}{|c|c|c|c|c|c|c|}
\hline $\begin{array}{l}\text { Char- } \\
\text { acter- } \\
\text { istics }\end{array}$ & $\begin{array}{l}\text { Com- } \\
\text { pared } \\
\text { groups }\end{array}$ & $\begin{array}{c}\mathrm{aHBs}>100 \\
\mathrm{mIU} / \mathrm{ml} \\
(\%) \\
\mathrm{n}=56\end{array}$ & $\begin{array}{c}\mathrm{aHBs}<100 \\
\mathrm{mIU} / \mathrm{ml} \\
(\%) \\
\mathrm{n}=42\end{array}$ & $\begin{array}{c}P- \\
\text { Value }\end{array}$ & $x^{2}$ & $\begin{array}{c}\mathrm{RR} \\
(95 \% \mathrm{CI})\end{array}$ \\
\hline \multirow[t]{2}{*}{$\begin{array}{l}\text { Age } \\
\text { (years) }\end{array}$} & $\begin{array}{c}\leq 40 \\
(n=60)\end{array}$ & $\begin{array}{c}42 \\
(70 \%)\end{array}$ & $\begin{array}{c}18 \\
(30 \%)\end{array}$ & \multirow[t]{2}{*}{$<0.001$} & \multirow[t]{2}{*}{20.6} & \multirow[t]{2}{*}{$\begin{array}{c}2.1 \\
(1.5-2.9)\end{array}$} \\
\hline & $\begin{array}{c}>40 \\
(n=38)\end{array}$ & $\begin{array}{c}14 \\
(36.8 \%)\end{array}$ & $\begin{array}{c}24 \\
(63.2 \%)\end{array}$ & & & \\
\hline \multirow[t]{2}{*}{ Gender } & $\begin{array}{l}\text { Female } \\
(n=59)\end{array}$ & $\begin{array}{c}38 \\
(64.4 \%)\end{array}$ & $\begin{array}{c}21 \\
(35.6 \%)\end{array}$ & \multirow[t]{2}{*}{0.016} & \multirow[t]{2}{*}{5.8} & \multirow[t]{2}{*}{$\begin{array}{c}1.5 \\
(1.1-2.1)\end{array}$} \\
\hline & $\begin{array}{c}\text { Male } \\
(n=39)\end{array}$ & $\begin{array}{c}18 \\
(46.2 \%)\end{array}$ & $\begin{array}{c}21 \\
(53.8 \%)\end{array}$ & & & \\
\hline
\end{tabular}

The Chi - square test was used to calculate the $P$ value. $\mathrm{RR}$ - relative risk; $\mathrm{Cl}$ - confidence interval.
In previous studies was demonstrated, that postvaccinal immunity is not only humoral, but it has been detected by HBsAg - specific T-lymphocytes (immunologic memory) persists long time after vaccination with serum antibodies $<10 \mathrm{mlU} / \mathrm{ml}$. The presence of immunological memory can be validated using a booster dose of vaccine, defined as anamnestic immunity.

According to medical records 17 health workers (out of 20 , who did not respond to the vaccine) received a booster dose (a fourth) of the vaccine. Seven of them have marked seroconversion (with anti-HBs $>10 \mathrm{lU} / \mathrm{ml}$ ).

Thus, in our research LSP $=[78 / 98+(20 / 98 \times 7 / 17)] \times$ $\times 100=87,7 \%$

In 34 persons $(34.6 \%)$ with a positive response to vaccination, the level of aHBs in a year after vaccination was in the range $\geq 10 \mathrm{mlU} / \mathrm{ml}<100 \mathrm{mlU} / \mathrm{ml}$, median 12 (12.0-35.1) $\mathrm{mlU} / \mathrm{ml}$, in 2 years - $10(3.0-26.0) \mathrm{mlU} / \mathrm{ml}$, and 3 years later it became negative Me- $6.0(3,0-11,0) \mathrm{mlU} / \mathrm{ml}$.

At a strong immune response $(\geq 100 \mathrm{mlU} / \mathrm{ml})$, titer of aHBs in 1 year after vaccination was 720 (251-1725) $\mathrm{mIU} / \mathrm{ml}$ and remained at a high level up to 10 years, and in 12 people - up to 12 years after vaccination. Of eight employees positive for aHBc, aHBs seroconversion after vaccination did not occur only in two.

Several studies have shown that reduction in aHBs titer does not necessarily reflect deterioration of protection against hepatitis B $[5,18]$, at the same time determination of the aHBs level remains the most costeffective measure of immunity to HBV infection.

These peculiarities of the dynamics and level of aHBs (weak immune response in $34.6 \%$ and negative in $20.4 \%$ of vaccinees), predictors of inefficiency of vaccination, will help to improve the monitoring of health care workers in the post-vaccination period and minimize the risks of failure of vaccination. This is comparable with the data of other authors [2, 13, 20], in which between $44.0 \%$ and $63.7 \%$ of HCWs did not respond to the vaccine. The debate continues on whether the anti-HBs titer more than $10 \mathrm{mIU} / \mathrm{ml}$ is sufficient to protect against hepatitis $B$ [9]. However, in this study, patients with a weak immune response $(a \mathrm{BBs}<100 \mathrm{mlU} / \mathrm{ml})$ became seronegative during three years after vaccination. Based on expert recommendations, follow-up of the primary immune response in risk medical personnel is necessary, which will specify more precisely the additional doses of the vaccine [6]. As well as in the study of J. Poorolajal (2009) [17], the introduction of a booster dose of the vaccine to HCWs, who did not respond to the vaccine (to activate the anamnestic immune response), allowed to increase the immunogenicity of the vaccine. At separation of the immune response into two categories in terms of 100 $\mathrm{mIU} / \mathrm{ml}$, additional information on sex characteristics is obtained, which is also comparable with other studies [3, 20]. Of 56 patients with a titer aHBs $\geq 100 \mathrm{mIU} / \mathrm{ml}$ after vaccination, men were only $46.2 \%$, and of 42 patients with a titer aHBs $<100 \mathrm{mIU} / \mathrm{ml}-53.8 \%$.

If one year after vaccination titer aHBs was more than $100 \mathrm{mlU} / \mathrm{ml}$, it remained at a high level for 9-13 years in $44(78.6 \%)$ patients (there is no data for the rest).

With increasing age, significant association with the absence of response to vaccination is revealed. Whereas under 25 all employees responded to the vaccine, after 50 years old seroconversion is detected only in $37.5 \%$. The dependence of the deterioration of response to vaccination with an increase in body mass index and HOMA index is revealed, which is comparable with the data of F. Averhoff et al. [1].

In literature there are data for association of absence of seroconversion to vaccination with smoking [1]. However, this study was limited by several factors: in 
particular, there was no information about smoking and other bad habits. Significantly higher levels of cholesterol ,triglycerides as well as an inadequate supply of 25(OH D in patients who do not respond to vaccination were probably associated with lipid disorders and obesity. Lack of seroconversion after vaccination in obese patients may be due to mechanical factors such as lack of dose relative to body size, or sub-optimal absorption and distribution of the vaccine against obesity.

Conclusions. The seroconversion rate after completion of scheduled vaccination was the same in our HCWs in comparison to HCWs working in other parts of the world. Vaccines against hepatitis B are highly immunogenic, but the presence of obesity and insulin resistance, increasing age of the patients older than

\section{References}

1. Averhoff F., Mahoney F., Coleman P., Schatz G., Hurwitz E., Margolis H. Immunogenicity of Hepatitis $B$ vaccines: Implications for persons at occupational risk of Hepatitis B virus infection Am J Prev Med. 1998;15(1):73-77.

2. Dannetun E. Teqneu A., Torner A., Giesecke J. Coverage of hepatitis B vaccination in Swedish health care workers. J Hosp Infect. 2006;63(2):201-204

3. Estevez Z. C., Betancourt A. A., Muzio G. V., Baile N. F., Silva C. V., Bernal F. H. Immunogenicity and safety assessment of the Cuban recombinant hepatitis $B$ vaccine in healthy adults. Biologicals. 2007:35(2):115-122.

4. Hepatitis B vaccines. Weekly Epidemiological Record 2009;84(40):405-420

5. Hollinger E. B., Kim C. N., Lee H. U. Factor influencing the immune response to hepatitis B Vaccine, booster dose Guideline and vaccine Protocol recommendation. Am J Med. 1989;16:365-403.

6. Health care personnel vaccination recommendations. Immunization Action Coalition. Technical content reviewed by the Centers for Disease Control and prevention, October 2009. http://www.immunize.org/ catg.d/p 2017.pdf

7. Resolution of the Chief State Sanitary Doctor of the Russian Federation on May 30, 2012 N '34 Moscow «On measures aimed at the elimination of acute hepatitis $\mathrm{B}$ in the Russian Federation http://www.rg.ru/2012/07/06/ onishenko-dok.html

8. Immunization of Health care workers. Recommendation of advisory committee on immunization practice (ACIP) and the Hospital Infection Control Practice Advisory committee (HICPAC). MMWR, Recommendation and report 26: 12/26/97.

9. Jack A. D., Hall A. J., Maine N., Meudy M., Whittle H. C. What level of hepatitis B antibody is protective? J Infect Dis. 1999; 179:489-492.

10. Kane A., Lloyd J., Zaffran M., Simonsen L., Kane M. Transmission of hepatitis $B$, hepatitis $C$ and human
40 years, male gender are associated with worsening response to vaccination.

The data on the dynamics of the aHBs titer, dictate the need to evaluate the immune response in HCWs (especially of high risk of infection and the presence of predictors to the absence of seroconversion). With a weak immune response $(>10 \mathrm{aHBs}<100 \mathrm{mlU} / \mathrm{ml})$ it is desirable to conduct annual monitoring of antibody titer with a view to the timely implementation of a booster dose of the vaccine at a decrease of aHBs $<10 \mathrm{mlU} / \mathrm{ml}$. In contrast, when the antibody titer is above $100 \mathrm{mIU} / \mathrm{ml}$, revaccination may not be required in the next 10 years.

Perhaps the appointment of vitamin D in HCWs with obesity and insulin resistance will help to increase the percentage of patients with seroconversion to vaccination.

immunodeficiency viruses through unsafe injections in the developing world: model-based regional estimates. Bull World Health Organ. 1999;(77):801-807.

11. Kao J. H. Chen D. S. Overview of Hepatitis B and C virus. In Infectious cause of cancer: target for intervention. Edited by: Guerdon T. J. J., Totowa N. J.: Humana press. 2000: 313-330.

12. Lasemi E., Haddadpour N., Navi F., Rakhshan A., Rakhshan V. Rate of Acquired Immunity in Dental Students after Hepatitis B Vaccination. Dent Res J. 2011;8(3):128-131.

13. Louther J., Feldman J., Rivera P., Villa N., DeHovitz J., Sepkowitz K. A. Hepatitis B vaccination program at a New York City hospital: Seroprevalence, seroconversion, and declination. Am J Infect Control. 1998;26(4):423-427.

14. Luiz A. S., Ciorlia I., Dirce M.T. Zanetta Hepatitis B in Health Care workers: Prevalence, vaccination and relation to occupational factor. The Brazilian journal of infectious disease. 2005;9(5):384-389.

15. Lupberger J., Hildt E. Hepatitis B virus-induced oncogenesis. World J Gastroenterol. 2007;13:74-81.

16. Platkov E., Shlyakhov E., Glick Y., Khalemsky S., Fischbein A. Immunologic evaluation of hepatitis $B$ vaccine application in hospital staff. Int $J$ Occup Med Environ Health. 2003;16(3):249-253.

17. Poorolajal J., Mahmoodi M., Majdzadeh R., NasseriMoghaddam S., Haghdoost A. A. et al. Seroprotection of hepatitis B vaccine and need for booster dose: a metaanalysis. Journal of Hepatitis Monthly. 2009;9(4):293304.

18. Roome A. J., Walsh S. J., Catter M. L., Haddle J. L. Hepatitis B vaccine responsiveness in Connecticut public safety personnel. JAMA. 1993;70:2931-2934.

19. WHO: Fact sheet 204; Hepatitis B.2015. URL:http://www/ who.int/ mediacentre/ factsheets/fs204/en/index.html.

20. Zeeshan M. Jabeen K. Nausheen A., Akbar A. Wilayat A. A. et al. Evaluation of immune response to Hepatitis B vaccine in health care workers at a tertiary care hospital in Pakistan: an observational prospective study. BMC Infectious Diseases. 2007;7:120.

\section{About authors:}

Tkachenko Larisa, MD, cms, Associate Professor of Department of Infectious Diseases with a Course of Phthisiology and APE; tel.: +7(8652)241986; e-mail: larisa308@mail.ru

Maleyev Viktor, MD, PhD, Academician of RAS, Professor, Deputy Director for Research of the Central Research Institute of Epidemiology; tel.: +79262969727; e-mail: maleyev@pcr.ru

Rtishcheva Ludmila, MD, cms, Associate Professor of Department of Infectious Diseases with a Course of Phthisiology and APE; tel.: +79280108977; e-mail:luda_doctor@mail.ru 